\title{
口蓋歯肉採取器の開発と臨床応用
}

\author{
長谷川明河野昭彦 \\ 日本歯科大学新潟歯学部歯周治療学教室 \\ (主任 : 長谷川明教授) \\ (昭和 61 年 9 月 20 日受付)
}

\section{A New Instrument for Obtaining the Graft from the Palate}

\author{
Akira HASEGAWA and Akihiko KONO \\ Department of Periodontics, Nippon Dental University, School of Dentistry at Niigata
}

(Chief : Prof. Akira HASEGAWA)

Several instruments to obtain the gigiva from the palate have been developed. In order to obtain wide graft, it is necessary that the curve of the blade fit to the shape of individual palate.

But the shape of the palate differs from person to person, so obtaining the grafts which is wide and thick as required, is not easy. It is ideal, if there is an instrument which can change the curve of the blade according to the shape of the palate.

We have developed an instrument which can change the curve of the blade by rotating the handle. The blade of this instrument can fit to the shape of the palate which differs from person to person and it can obtain easily the widest palatal gingiva and furthermore, it is easy to manage in the oral cavity.

Key words : Instrument for obtaining the palatal gingiva, Shape of the palate

要旨 : 口蓋部の歯肉を採取する器具としては, 現在までに種々のものが開発されているが, 幅の広い歯肉片を採取 するためには, 患者の口蓋の形態に適合する刃部の彎曲が必要である。しかし, 口蓋の形態には個人差があり, 必要 とする厚さと幅の歯肉片を採取するのは必ずしも容易なことでない。それぞれの患者の口蓋の形態に応じて，刃部の 彎曲を変えることのできる器具があれば理想的である。

今回, 把柄部を回転することによって刃部の彎曲を自由にかえることができる口蓋歯肉採取器を開発した。本器は, 各個人で異なる口蓋の形態に刃部を適合させることが可能で, 最大面積の口蓋歯肉が容易に採取でき，また口腔内に おける操作性もすぐれている。

索引用語 : 口蓋歯肉採取器, 口蓋形態

\section{緒言}

歯周治療の過程における遊離歯肉移植手術は, 付着歯 肉幅の増大, 口腔前庭の拡張, 小帯切除後のあと戻りの 防止, 歯肉退縮による露出根面の被覆などの目的で行わ れており, その際の歯肉採取部位としては多くの場合, 口蓋が選ばれている。
口蓋部の歯肉を採取する器具としては, 現在までに種 々のものが開発されているが, ある程度幅の広い歯肉片 を採取するためには，患者の口蓋の形態に適合する刃部 の彎曲が必要である。しかし，口蓋の形態には個人差が あり, 必要とする厚さと幅の歯肉片を採取するのは必ず しも容易なことではない。それぞれの患者の口蓋の形態 に応じて, 刃部の彎曲を変えることのできる器具があれ ば理想的である。

\footnotetext{
本論文の要旨は, 第 28 回春季日本歯周病学会総会（1985 年 6 月 6 日）において発表した。
} 


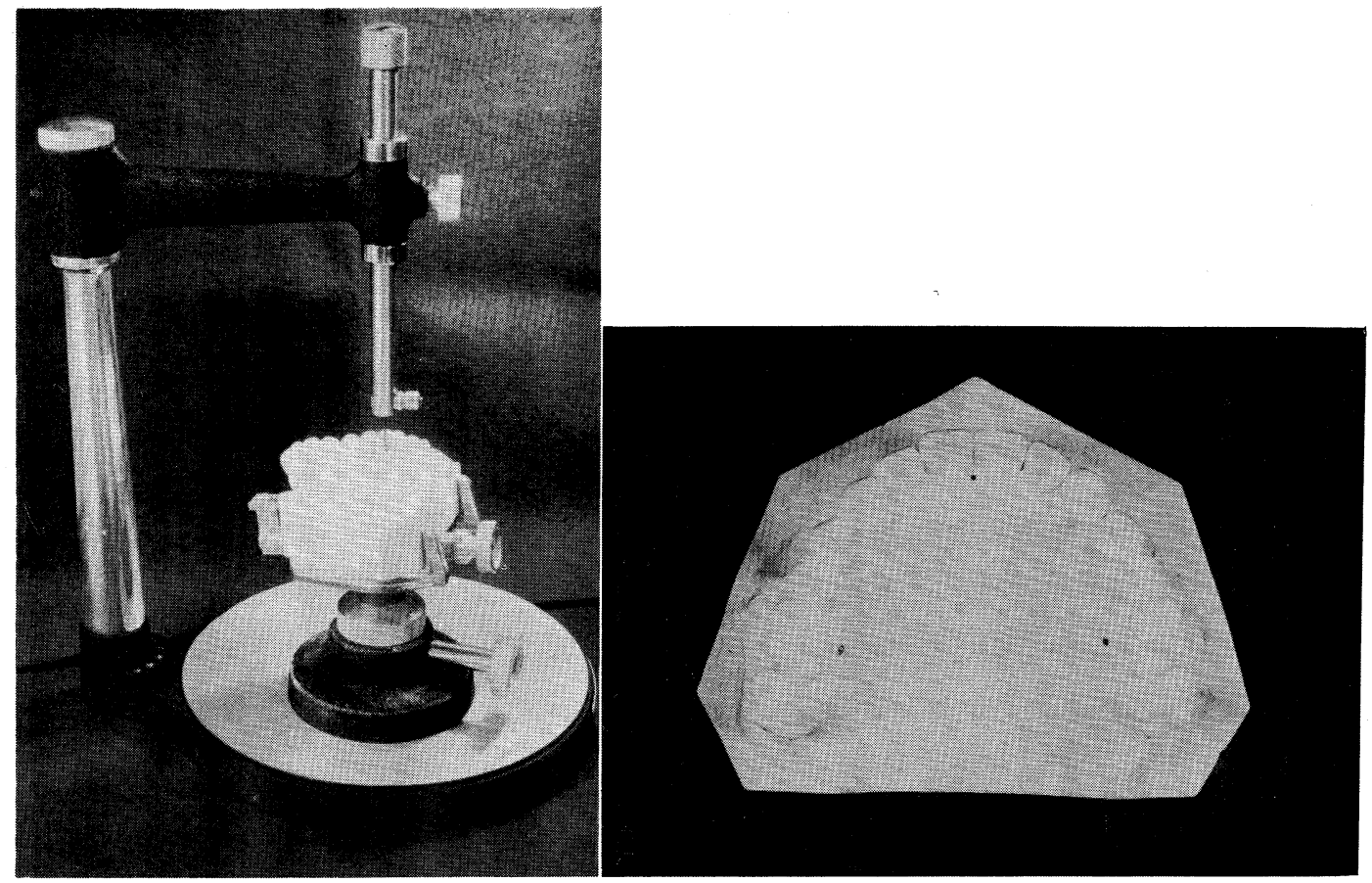

図 1 基準点とサベイヤーによる水平基準面の決定

当教室では，このような観点から，口蓋歯肉採取器の 開発を試みてきたが，このたび一応の完成をみることが できた。

今回は，患者の口腔内石膏模型によって検討した口蓋 歯肉採取部の広さ, 彎曲などについての研究も含め, 日 本歯科工業社の協力を得て, 当科で開発した口蓋歯肉採 取器について報告する。

\section{口蓋蒾肉採取に必要な口蓋形態 に関する研究}

口蓋から歯肉を採取するのにふさわしい部位は，口蓋 縫線また，横口蓋ヒダを避けた硬口蓋部である。しか し，これらの範囲がどの程度であり，また，その部の口 蓋彎曲がどの位なのかといった研究は少ない。そこで, まず，口蓋歯肉採取部位に必要な口蓋の形態について検 索した。

\section{1. 研究材料と研究方法}

1) 研究材料

研究材料は，当科所蔵の患者石膏模型の中から正常歯 列を有すると思われる 50 例を無作為に抽出し，これを 使用した。年齢は 23〜59 歳で男性 30 例, 女 性 20 例 で
あった。

2）研究方法

切歯乳頭頂と左右第 1 大臼歯口蓋側歯肉緣の 3 点を基 準点とし，これらを NEY 社，サベイヤーを用いて決定 した。この 3 基準点を含む平面を水平基準面とした（図 1)。

石膏模型の切断は，ヨシダ社, HI-SEVER を用い，水 平基準面に垂直になるようにし，左右第 2 小臼歯口蓋側 歯肉縁間，左右第 1 大臼歯口盍側歯肉縁間，左右第 2 大 日歯口蓋側歯肉縁間を直線で結ぶ 3 力所で行った（図 2)。

このようにして，3 部位で切断された模型の断面を複 写機（キャノンNP-400 RE）でコピーし，これを分析し た(図 3)。

2. 成 績

1) 横口蓋ヒダの最後方位置

横口蓋七ダの最後方位置（図 4) は，第 1 小臼歯の中 央部から第 1 大臼歯の近心部の範囲にあり，第 2 小臼歯 に位置するものが，大多数を占めた。

以上のことから，第 1 小臼歯より後方の口蓋歯肉が多 くの場合，採取適応部位であることがわかった（表 1)。

2）第 2 小臼歯中央部より第 2 大臼歯中央部までの長 


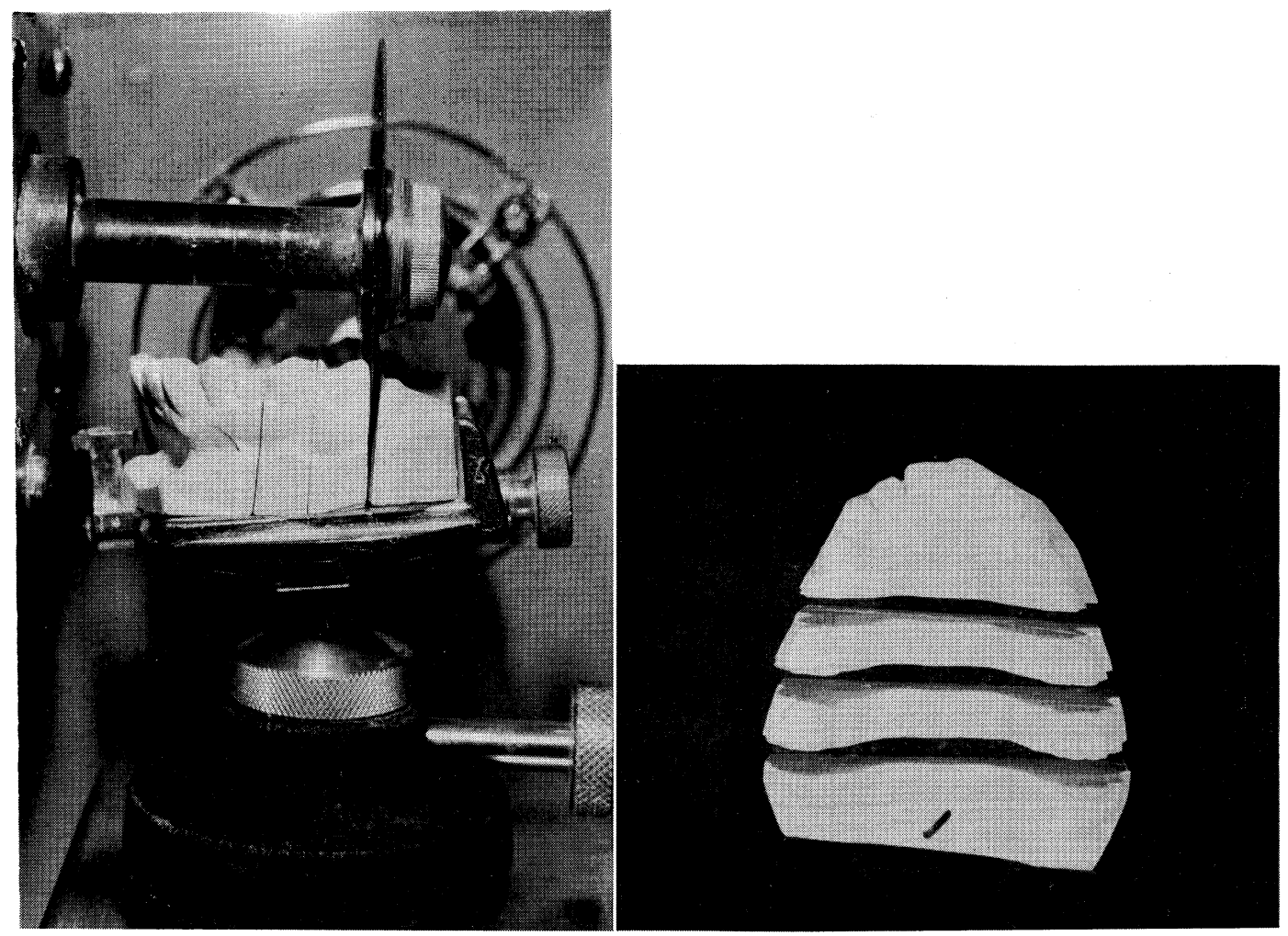

図 2 石膏横型の切断

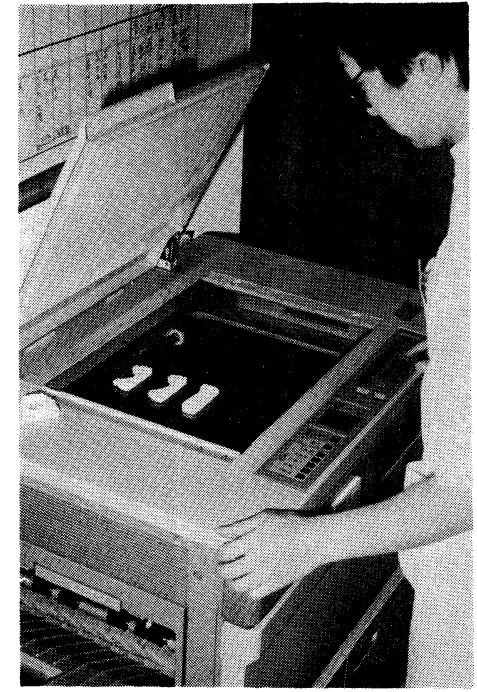

図 3 切断模型断面を複写機にてコピー

さ

横口蓋七ダの最後方位置を第 2 小臼歯の中央部とし, これより，歯肉採取後方限界である第 2 大臼歯中央部ま

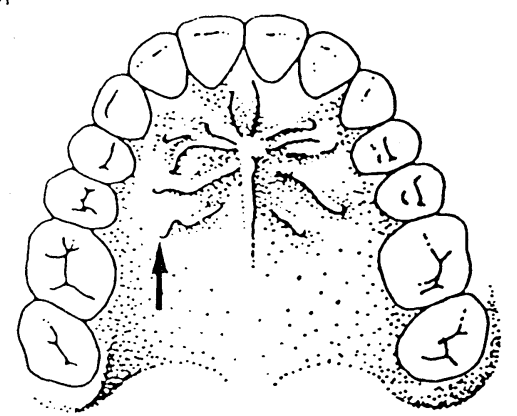

図 4 横口蓋ヒダの最後方位置

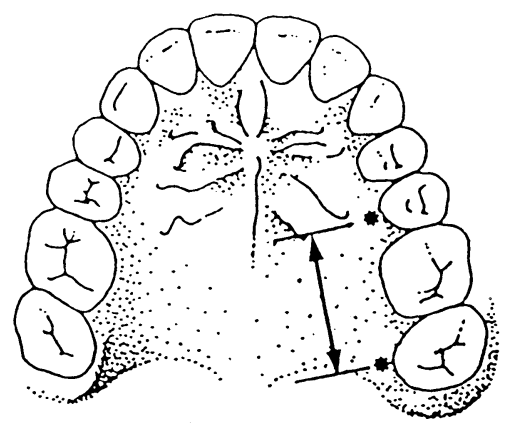

図 5 第 2 小臼歯より第 2 大臼歯中央部までの長さ 


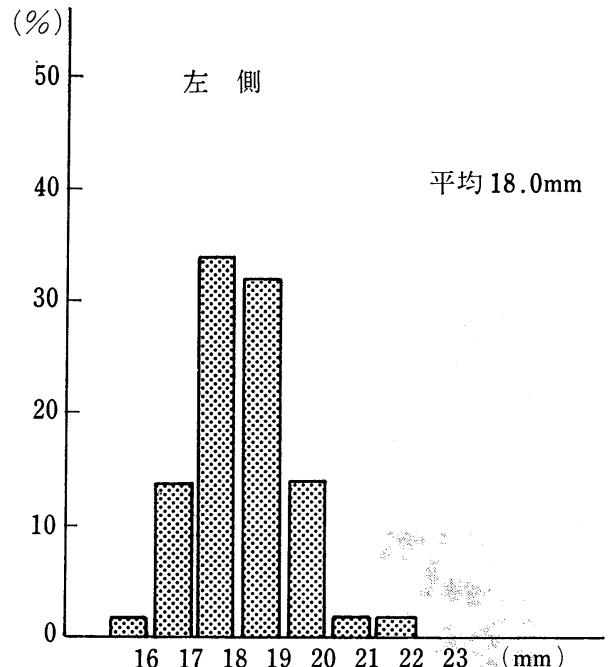

図 6 第 2 小田歯中央部より第 2 大臼歯中央部までの長さ
表 1 横口蓋ヒダの最後方位置

\begin{tabular}{|c|c|c|c|}
\hline 部 位 & 百分率 & $\begin{array}{c}\text { 右 側 } \\
\% \text { (例数) }\end{array}$ & $\begin{array}{c}\text { 左 側 } \\
\% \text { (例数) }\end{array}$ \\
\hline \multirow{3}{*}{ 第 1 小臼歯 } & 近 心 & $0 \quad(0)$ & $(0)$ \\
\hline & 中 央 & $2.0(1)$ & $6.0(3)$ \\
\hline & 遠 心 & $2.0(1)$ & $8.0(4)$ \\
\hline \multirow{3}{*}{ 第 2 小臼歯 } & 近 心 & 38.0 (19) & $42.0 \quad(21)$ \\
\hline & 中 央 & $32.0 \quad(16)$ & 38.0 (19) \\
\hline & 遠 心 & $24.0 \quad(12)$ & $6.0(3)$ \\
\hline \multirow{3}{*}{ 第 1 大臼歯 } & 近 心 & $2.0(1)$ & $(0)$ \\
\hline & 中 央 & $0 \quad(0)$ & $(0)$ \\
\hline & 遠 心 & $(0)$ & $(0)$ \\
\hline
\end{tabular}

での長さを計測してみた（図 5)。

この部の長さは, $16 \mathrm{~mm}$ から $22 \mathrm{~mm}$ で平均約 $18 \mathrm{~mm}$ であった（図 6)。

以上のことから，口蓋歯肉の採取可能な長さは多くの 場合, $18 \mathrm{~mm}$ であることが分かった。

一方, 横口蓋ヒダの最後方位置が認められる最先方位 置である第 1 小眠歯中央部より第 2 大臼歯中央部までの 長さは (図 7), $22 \mathrm{~mm}$ から $28 \mathrm{~mm}$ で平均約 $25 \mathrm{~mm}$ で あった（図 8)。

以上のことから，個人によっては $25 \mathrm{~mm}$ までのの採 取が可能であることが分かった。

3） 口蓋前額彎曲

江西 ${ }^{1)}$ 分類にしたがい，口蓋彎曲を, A : V 字型, B :

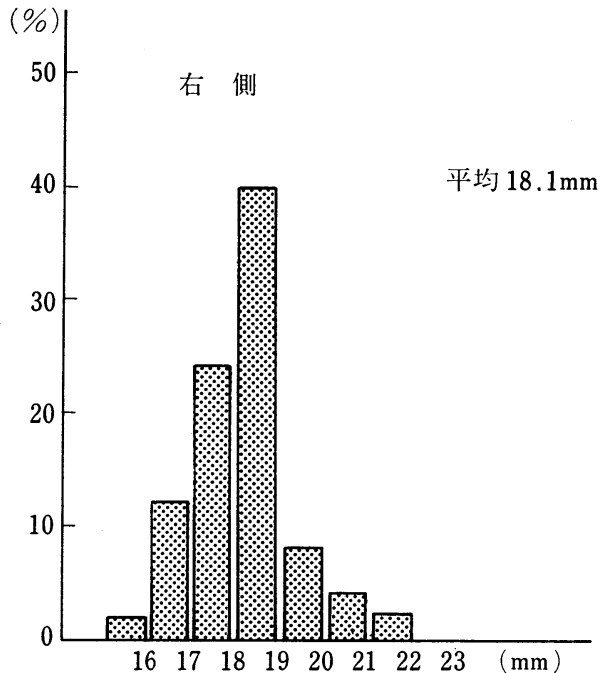

$\begin{array}{llllllllll}16 & 17 & 18 & 19 & 20 & 21 & 22 & 23 & (\mathrm{~mm})\end{array}$

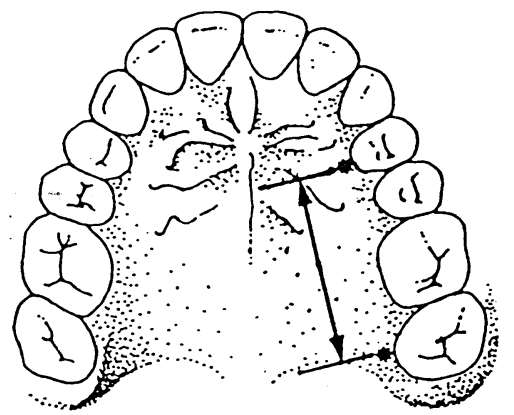

図 7 第 1 小臼歯中央部より第 2 大臼歯中 央部までの長さ

放物線型， C : 中央凹型， D : 帯円型， E : 中央凸型， $\mathrm{F}$ : 方形型, の 6 型に分け (図 9), その出現率を第 2 小臼歯 部，第 1 大臼歯部，第 2 大臼歯部について検索した。

(1) 第 2 小臼歯部

最も多かったのは帯円型で約半数近くを占め, 次いで, 中央凸型, 方形型, $\mathrm{V}$ 字型の順であった。

(2) 第 1 大臼歯部

最も多かったのは帯円型で半数以上を占め, 次いで, 中央凸型, 放物線型の順であった。

(3) 第 2 大臼歯部

最も多かったのは帯円型で半数以上を占め, 次いで放 物線型, 中央凸型の順であった（表 2)。

以上のことから，口蓋前額彎曲は，第 2 小臼歯，第 1 大臼歯, 第 2 大臼歯の各部において, 帯円型のものが半 

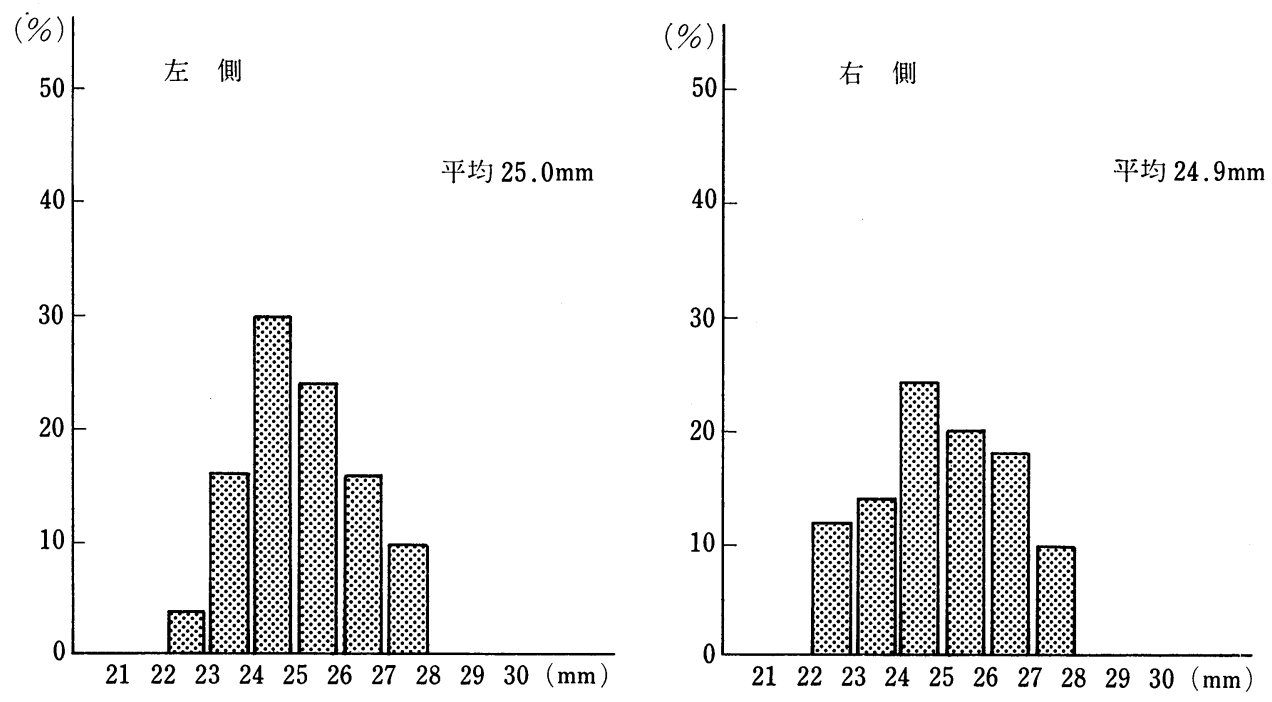

図 8 第 1 小臼歯中央部より第 2 大臼歯中央部までの長さ

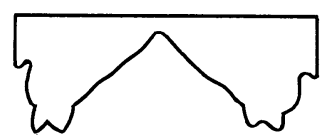

$\mathrm{V}$ 字型

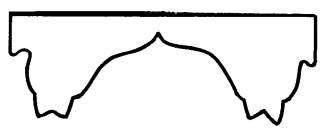

中央凹型

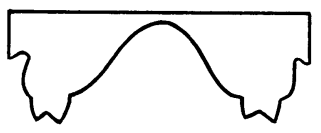

放物線型

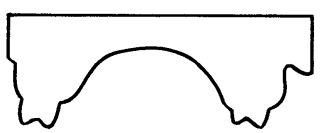

带円型

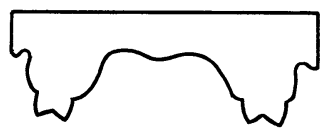

中央凸型

図 9 口蓋前額彎曲(江西の分類)

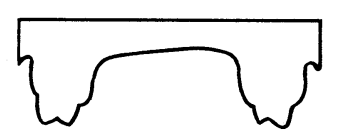

方形型
数近くかそれ以上を占め, 次いで, 第 2 小臼歯, 第 1 大 且歯部では中央凸型, 第 2 大臼歯部では放物線型の順で あった。

4） 口蓋歯肉採取部の口蓋前額彎曲

口蓋歯肉を採取する部位である小臼歯, 大曰歯歯肉縁 より口蓋正中までの口蓋前額彎曲は, $\mathrm{A}$ ：直線型, B : 凸 型, C : 凹型, D : S 字型に分類できた (図 10)。その結 果, 第 2 小臼歯部では凸型が最も多く, 次いで, 直線型 であり，両者の割合はほぼ同数で，両者合わせると $80 \%$
表 2 口蓋前額彎曲(江西の分類)

\begin{tabular}{|c|c|c|c|}
\hline 百分率 & $\begin{array}{c}\text { 第 } 2 \text { 小臼歯部 } \\
\% \text { (例数) }\end{array}$ & $\begin{array}{c}\text { 第 } 1 \text { 大臼歯部 } \\
\% \text { (例数) }\end{array}$ & $\begin{array}{c}\text { 第 } 2 \text { 大臼歯部 } \\
\% \text { (例数) }\end{array}$ \\
\hline $\mathrm{V}$ 字 型 & $14.0(7)$ & $4.0(2)$ & $2.0(1)$ \\
\hline 放物線型 & $4.0(2)$ & $16.0(8)$ & $24.0 \quad(12)$ \\
\hline 中央凹型 & $0 \quad(0)$ & $0 \quad(0)$ & $4.0(2)$ \\
\hline 帯 円 型 & $48.0 \quad(24)$ & 54.0 & 54.0 \\
\hline 中央凸型 & $18.0(9)$ & $18.0(9)$ & $16.0(8)$ \\
\hline 方 形 型 & $16.0(8)$ & $8.0(4)$ & $0 \quad(0)$ \\
\hline
\end{tabular}

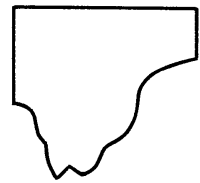

$\mathrm{S}$ 字型

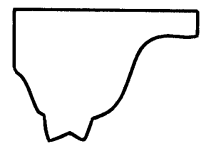

凸 型

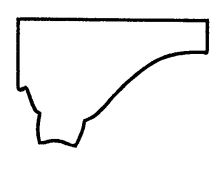

直線型

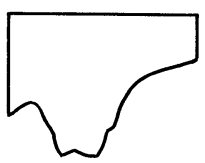

凹 型
図 10 口蓋歯肉採取部の口蓋前額彎曲

以上を占めた。

第 1 大臼歯部では, 直線型が, $80 \%$ に近く, 次いで, 
表 3 口蓋歯肉採取部の口蓋前額彎曲

(右側)

\begin{tabular}{|c|c|c|c|}
\hline 百分率 & $\begin{array}{c}\text { 第 } 2 \text { 小臼歯部 } \\
\% \text { (例数) }\end{array}$ & $\begin{array}{c}\text { 第 } 1 \text { 大臼歯部 } \\
\% \text { (例数) }\end{array}$ & $\begin{array}{c}\text { 第 } 2 \text { 大臼歯部 } \\
\% \text { (例数) }\end{array}$ \\
\hline 直線型 & $40.0 \quad(20)$ & 78.0 & $34.0 \quad(17)$ \\
\hline 凸 型 & 42.0 & $4.0(2)$ & $4.0(2)$ \\
\hline 凹 型 & $12.0(6)$ & $18.0(9)$ & $52.0 \quad(26)$ \\
\hline $\mathrm{S}$ 字型 & $6.0(3)$ & $0 \quad(0)$ & $10.0(5)$ \\
\hline \multicolumn{4}{|c|}{ （左側） } \\
\hline 弯曲型 & $\begin{array}{c}\text { 第 } 2 \text { 小臼歯部 } \\
\% \text { (例数) }\end{array}$ & $\begin{array}{c}\text { 第 } 1 \text { 大臼歯部 } \\
\% \text { (例数) }\end{array}$ & $\begin{array}{c}\text { 第 } 2 \text { 大臼歯部 } \\
\% \text { (例数) }\end{array}$ \\
\hline 直線型 & $42.0 \quad(21)$ & $78.0 \quad(39)$ & $40.0 \quad(20)$ \\
\hline 凸 型 & $44.0 \quad(22)$ & $6.0(3)$ & $2.0(1)$ \\
\hline 凹 型 & $10.0(5)$ & $16.0(8)$ & 48.0 \\
\hline $\mathrm{S}$ 字型 & $4.0(2)$ & $0 \quad(0)$ & $10.0(5)$ \\
\hline
\end{tabular}

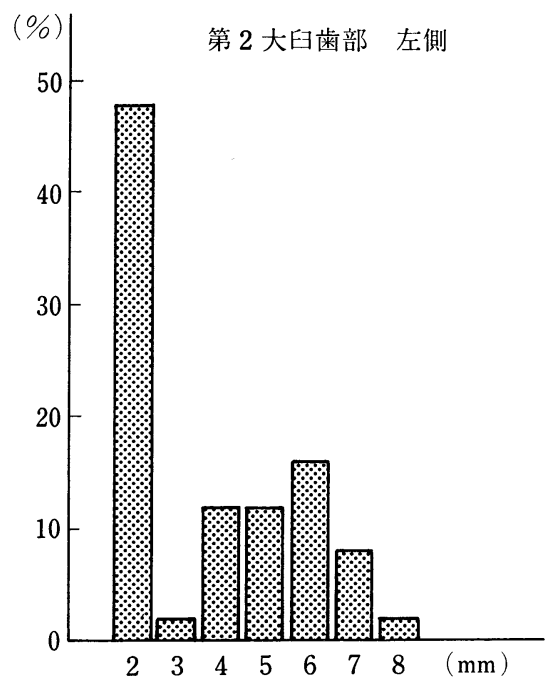

表 43 部位での彎曲の変化

(右側)

\begin{tabular}{l|l}
\hline & $\%$ (例数) \\
\hline 3 部位とも同様な弯曲 & $20.0(10)$ \\
\hline 2 部位が同様な弯曲 & $52.0(26)$ \\
\hline 3 部位とも異なる弯曲 & $28.0(14)$ \\
\hline \multicolumn{2}{|c}{ (左側) } \\
\hline 3 部位とも同様な弯曲 & $22.0(11)$ \\
\hline 2 部位が同様な弯曲 & $54.0(27)$ \\
\hline 3 部位とも異なる弯曲 & $24.0(12)$ \\
\hline
\end{tabular}

図 11 歯頸部近接口蓋崡肉部彎曲の測定部位

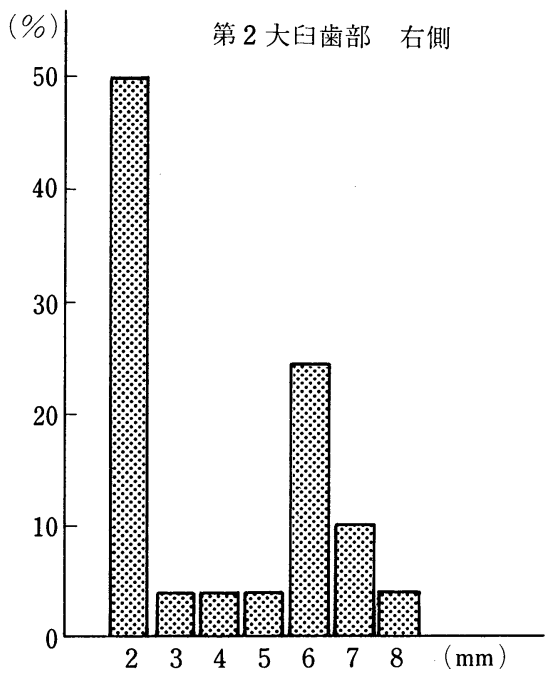

図 12 歯頸部近接口蓋歯肉部の彎曲

凹型で，両者を合わせると $90 \%$ 以上を占めた。

第 2 大臼歯部では, 凹型が最も多く, 次いで直 線 型 で，両者合わせると $90 \%$ 近くを占めた（表 3 ）。

以上より, 第 2 小臼歯では, 半数近くが, 厚く歯肉採 取される可能性があるが，大臼歯部ではそのような傾向 は少ないことが分かった。
さらに第 2 小臼歯, 第 1 大臼歯, 第 2 大臼歯の 3 部位 での彎曲の変化を調べてみると 2 部位が同じ彎曲を示す ものが, 半数以上で, 次いで 3 部位とも異なる彎曲を示 すものが $30 \%$ 近くを占めた（表 4 ）。

このことは, 歯肉採取時の刃部の角度を始めから終わ りまで同一彎曲で行なうと採取された歯肉片の厚さが不 

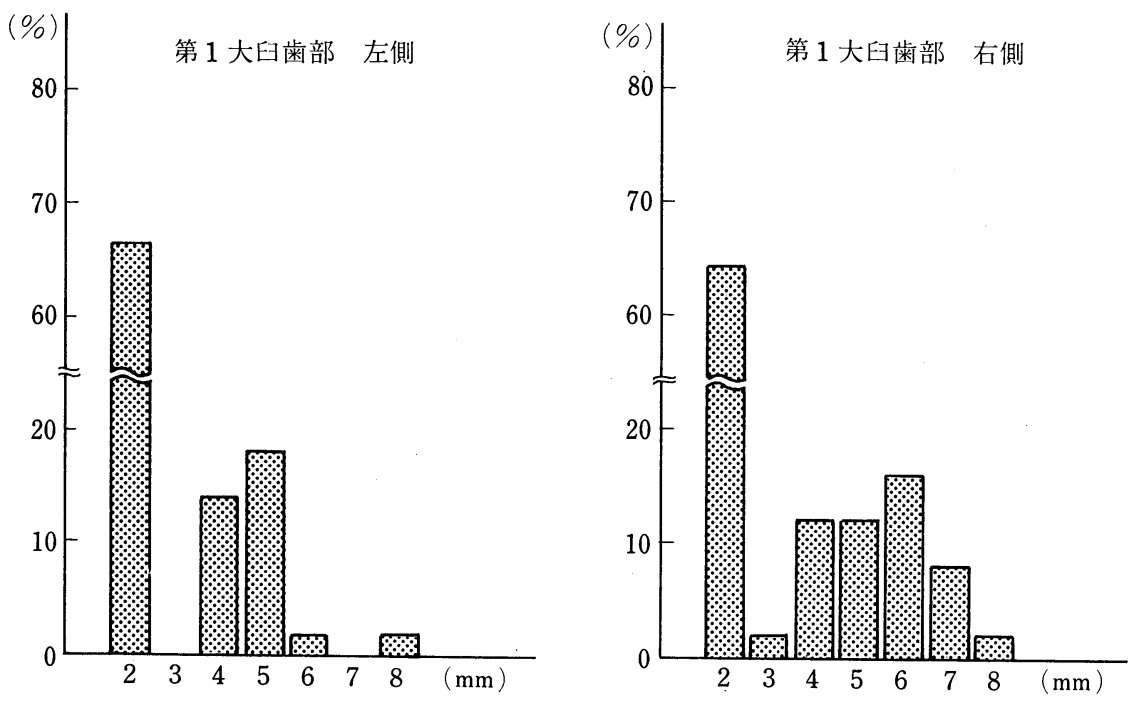

図 13 歯頸部近接口蓋歯肉部の彎曲
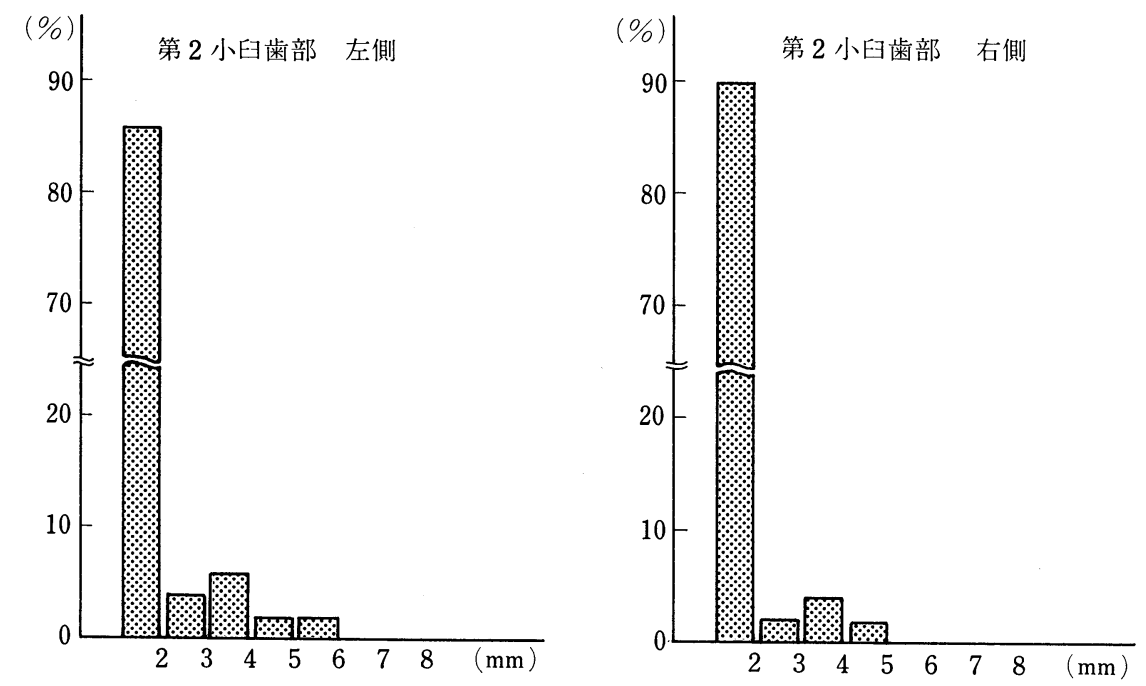

図 14 歯頸部近接口蓋歯肉部の彎曲

均一になることを示している。

\section{5）歯頸部近接口蓋歯肉部の彎曲}

実際の歯肉採取に当たっては歯頸部近接口蓋歯肉部の 彎曲が採取される歯肉の幅に影響を及ぼす。この部に凸 型の彎曲がある場合はその部を避けた位置から歯肉の採 取を行うことになる（図 11）。この部の彎曲は第 2 大臼 歯部では半数近くに見られ，歯肉縁から彎曲部が消失す るまでの距離は, $8 \mathrm{~mm}$ に達するものもあった (図 12)。 第 1 大臼歯部では，彎曲の認められるもの が，約 $30 \%$ となり, 5〜 6 mm の範囲を示すものが多かった (図 13)。
第 2 大臼歯では, 彎曲の認められるものの割 合 が減 少 し, 約 $10 \%$ となり 3〜 $4 \mathrm{~mm}$ の範囲を示すものが多かっ た(図 14)。

6）口蓋側歯肉縁より口蓋正中方向への斜面距離 前額断面で口蓋側歯肉を見ると歯肉を採取できる斜面 部と天蓋部がある（図 15）。歯肉を採取できる範囲であ る口蓋側歯肉縁から口蓋正中方向への斜面距離は, 第 2 小曰歯部では約 $15 \sim 16 \mathrm{~mm}$, 第 1 大臼歯部では 16〜17 $\mathrm{mm}$, 第 2 大臼歯部では 16〜18 mm であった (図 16,17 , 18)。 
採取される歯肉の幅は，以上の長さとなるが，歯頸部 近接口蓋歯肉部に彎曲がある場合には，これを差し引い た長さとなる。したがって, 第 2 小臼歯部では, $90 \%$ 位 が 15〜16 mm であり, 第 1 大臼歯部では, $70 \%$ 位が 16 17 mm であり, 第 2 大臼歯部では, 約半数が $16 \sim 18$

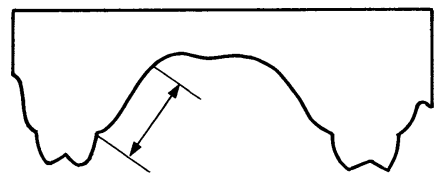

図 15 口蓋側歯肉縁より口蓋正中方向 への斜面距離の測定部位

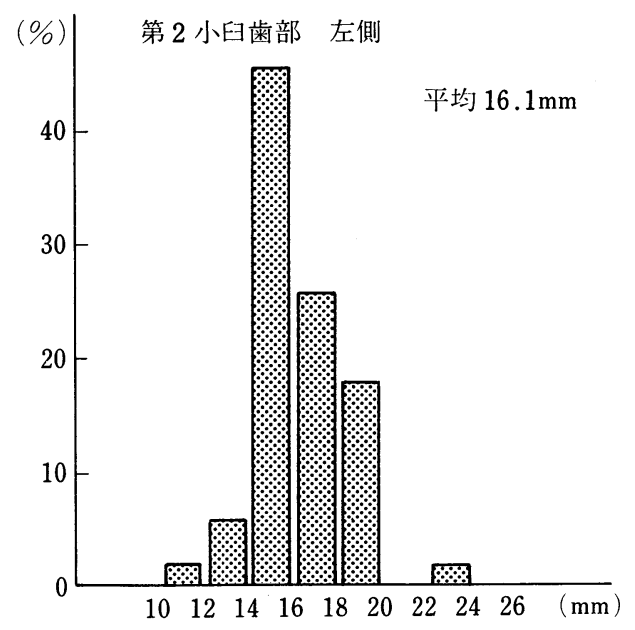

図 16 口蓋側歯肉縁上り口蓋正中方向への斜面距離
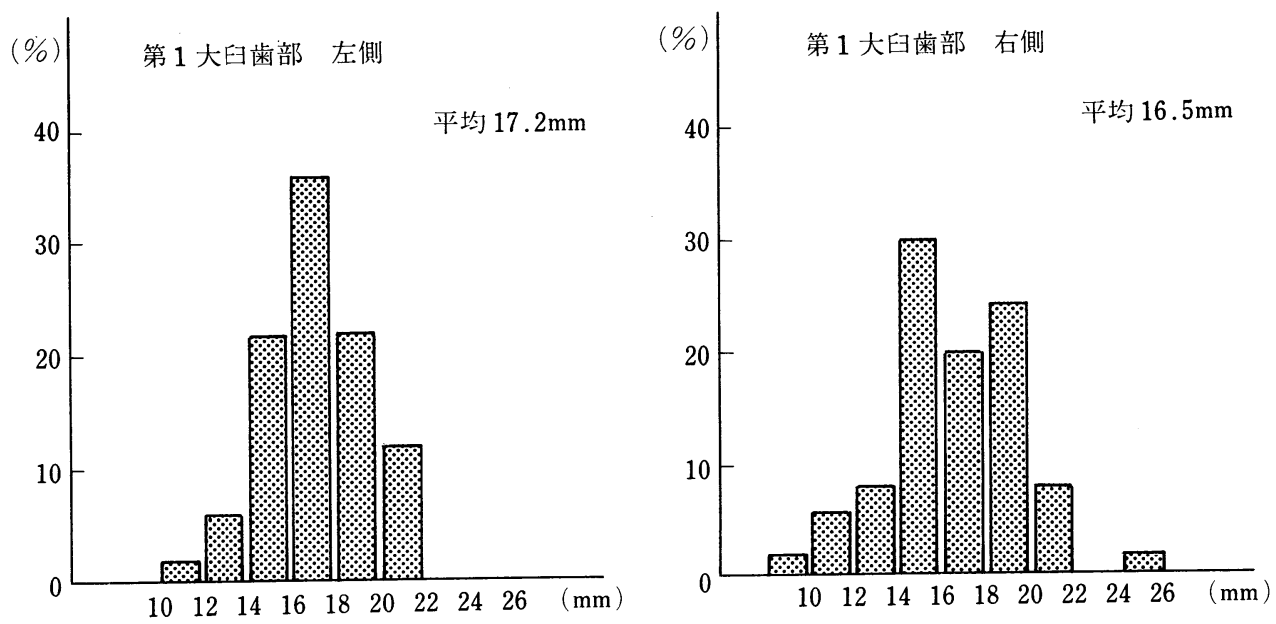

\section{1. 特 長}

本器は全長 $16 \mathrm{~cm}$ で把柄部, 接続部, 刃部よりなっ ており，把柄部を回転することによって，刃部の彎曲を 自由に変えることができる。さらに接続部も容易に屈曲 でき, 各個人で異なる口蓋の形態に刃部を簡単に適合さ せることができる。これによって最大面積の口蓋歯肉採 取が可能である (図 19)。

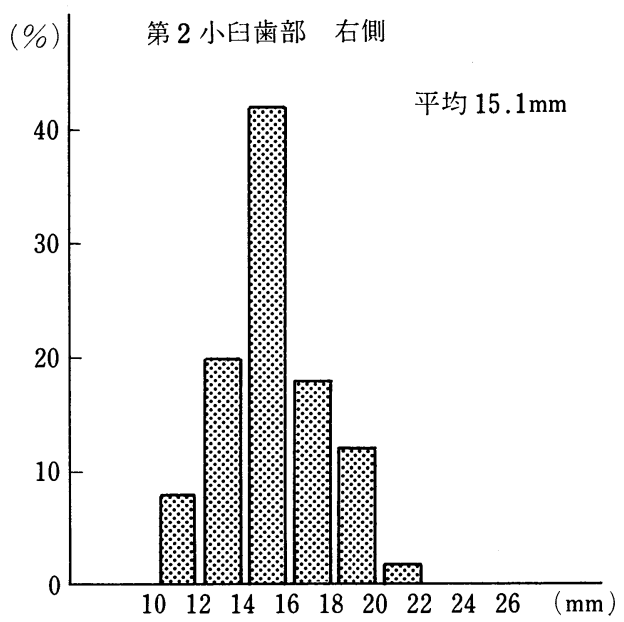

$\mathrm{mm}$, 残る半数は，これより $8 \mathrm{~mm}$ までの範囲で幅が減 少することになる。

\section{口蓋歯肉採取器の特長と使用法}

図 17 口蓋側歯肉縁上り口蓋正中方向への斜面距離 


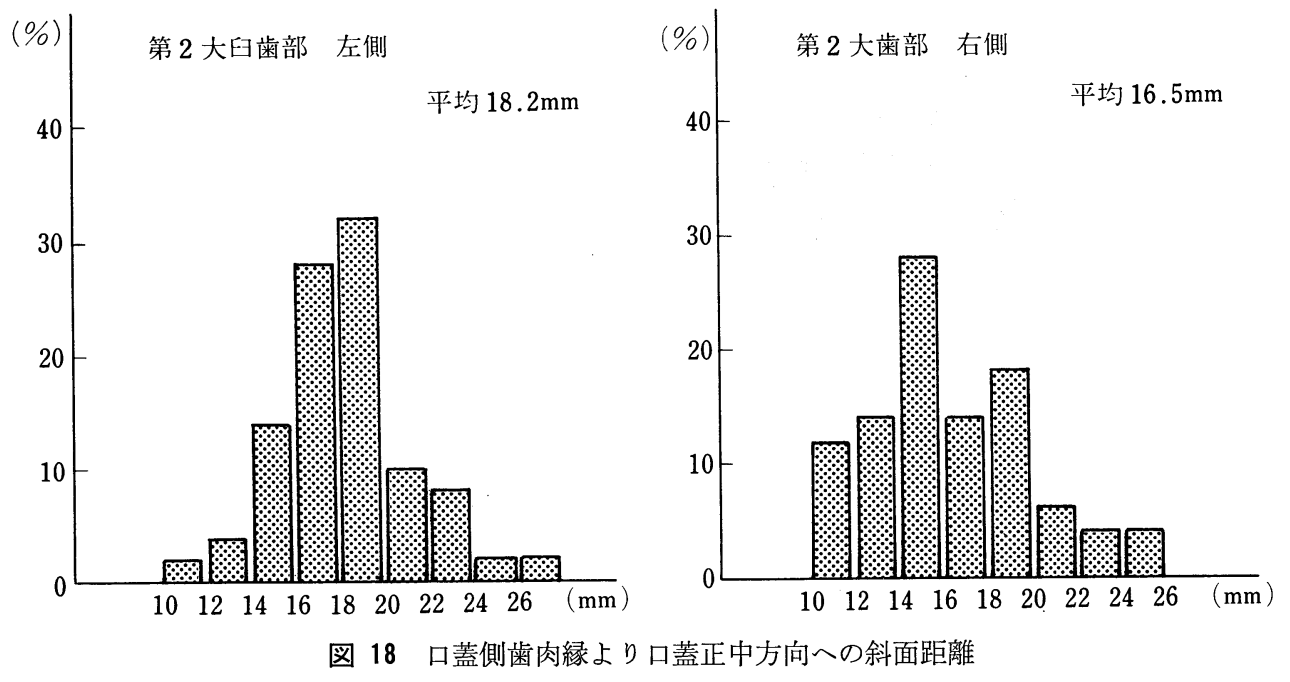

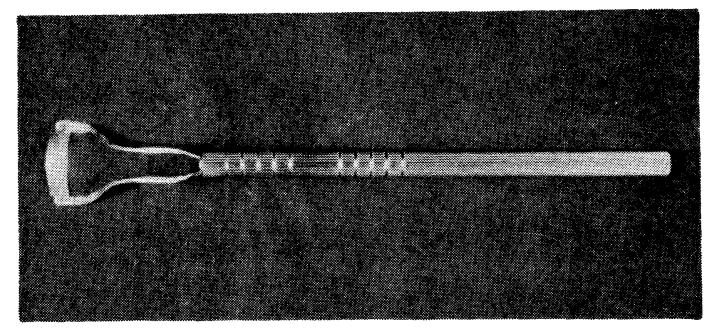

図 19 口蓋歯肉採取器

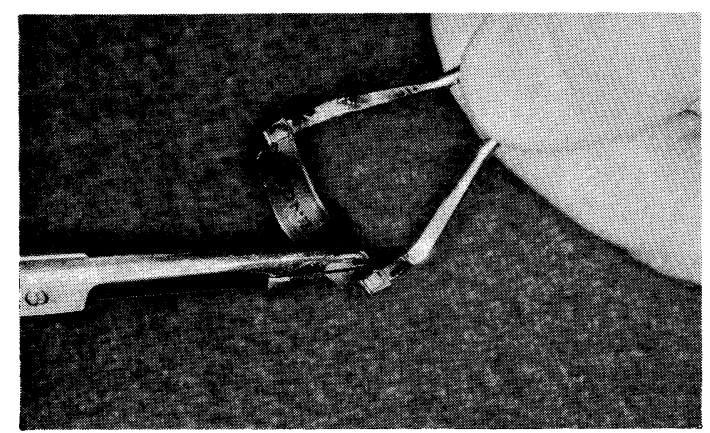

図 20 刃部の取付け

\section{2. 刃部の取り付け}

替刃式の刃部は長さが $2 \mathrm{~cm}$ でこれを, 把柄側に刃先 が向くように接続部先端の，刃把持部に挿入する。これ だけで刃部は本体にしっかりと固定される（図 20）。

\section{3. 刃部彎曲の調整}

一方の手で接続部を把持し，他方の手で把柄部を回転 すると刃部の彎曲が得られる（図 21）。患者のスタディ モデルで刃部の彎曲を予め調整しておくと実際の使用に

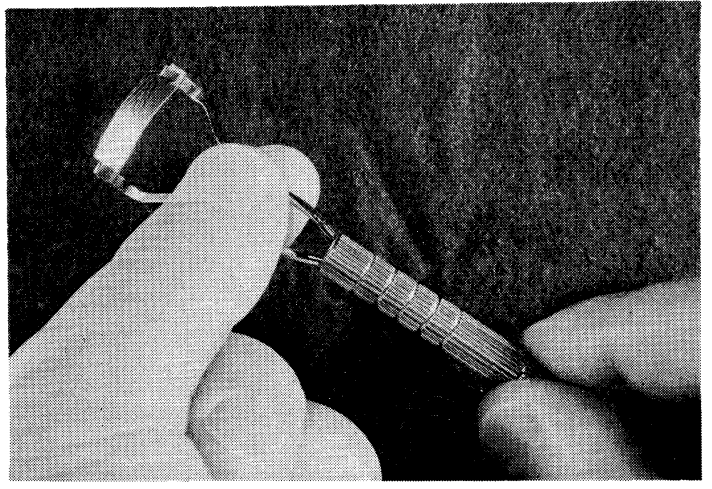

図 21 刃部彎曲の調整

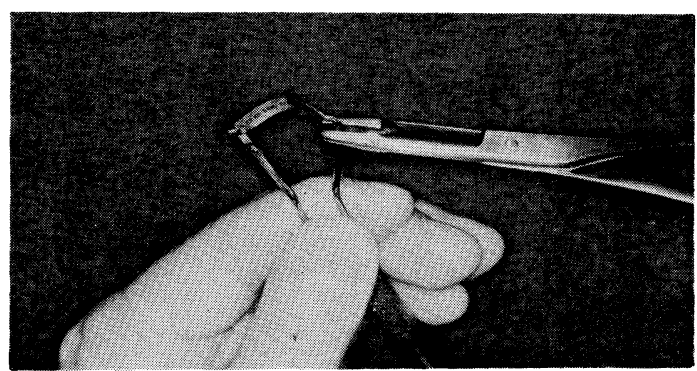

図 22 接続部の屈曲による刃部角度の調整

当たり, 便利である。さらに接続部の屈曲が必要な場合 には，適当なプライヤーで接続部に屈曲を与えることが できる (図 22)。以上の操作によって, 刃部の片側が採 取を予定している口蓋部に広く接触するように調整す る。 


\section{4. 口蓋歯肉の採取}

口蓋における歯肉採取予定部の外形に一致して，予め 尖刃刀で深さ約 $1 \mathrm{~mm}$ の切開を加える（図 23）。次いで, 本器を外形切開の後端に当て, 刃部をある程度歯肉内に くい込ませたのち, 徐々に前方に移動する（図 24）。口 蓋の彎曲が変化し，歯肉の採取が思うようにいかなくな ったら, その時点で, 一度, 本器をはなし, 刃部彎曲の 調整を行い，ふたたび採取を開始する。

\section{5. 付属品とその使用法}

刃部は替刃式で接続部も交換式である。刃部はステン レスのカミソリ刃，接続部はステンレス鋼 420-J-2，把 柄部はシンチュウ BSBM-1 のクロムメッキ仕上げで, 接続部と把柄部は高圧蒸気滅菌装置（オートクレーブ） により滅菌が可能である。

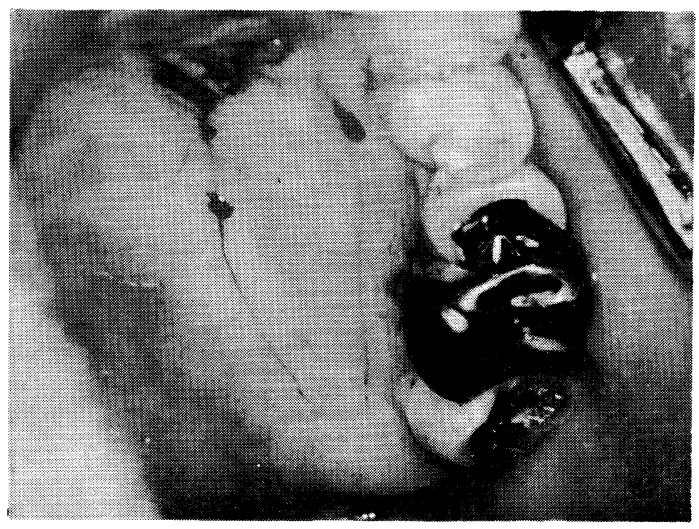

図 23 口蓋の歯肉採取予定部に外形切開

\section{口蓋歯肉採取器による歯肉の採取幅}

口蓋歯肉がどのような範囲で採取可能かについては， 先きに述べたが，その部から実際に採取される歯肉片の 幅は，使用する器具によって異なってくる。

そこで本器による採取歯肉片の幅について検索してみ た。

まず, 本器, 接続部先端の刃把持部閒の距離を最大の $20 \mathrm{~mm}$ にした場合を大彎としこれをせばめて $16 \mathrm{~mm}$ に した場合を小彎として, 口蓋歯肉採取部の口蓋前額彎曲 の分類, すなわち, 直線型, 凸型, 凹型, $\mathrm{S}$ 字型別に計 測し, 平均值を算出した。

その結果，歯肉の採取幅は， 凹型で最も大きく 12.0 $\mathrm{mm}$, 次いで, 直線型の $10.6 \mathrm{~mm}, \mathrm{~S}$ 字型の $9.0 \mathrm{~mm}$, 凸 型の $8.6 \mathrm{~mm}$ であり, 刃部の彎曲度別では, 凹型におい て大彎，小彎で $3 \mathrm{~mm}$ 近くの差が認められる以外，他の 分類型では，ほとんど差がなかった（表 5)。

なお採取される歯肉の厚さは， $\mathrm{S}$ 字型，凸型では厚く

表 5 口蓋歯肉採取器による歯肉の採取幅

\begin{tabular}{c|c|c|c}
\hline 弯曲形 & 大弯 $(\mathrm{mm})$ & 小弯 $(\mathrm{mm})$ & 平均 $(\mathrm{mm})$ \\
\hline 直線型 & 10.7 & 10.4 & 10.6 \\
\hline 凸 型 & 8.8 & 8.4 & 8.6 \\
\hline 凹 型 & 13.4 & 10.6 & 12.0 \\
\hline $\mathrm{S}$ 字型 & 9.1 & 8.9 & 9.0 \\
\hline ※刃把持部間距離 大弯 & $\begin{array}{l}20.0 \mathrm{~mm} \\
\text { 小弯 }\end{array}$ & $16.0 \mathrm{~mm}$
\end{tabular}

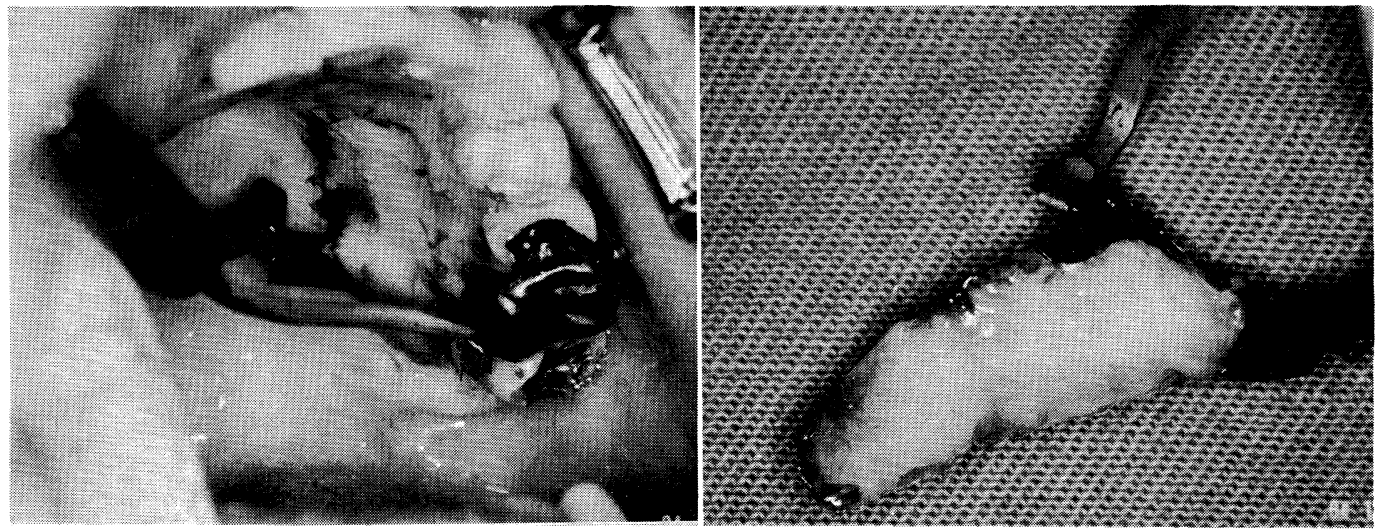

図 24 前方に移動し歯肉を採取 


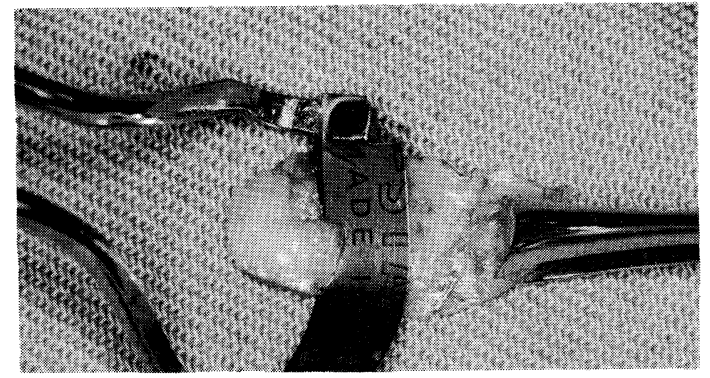

図 25 口蓋歯肉採取器による余分な組織の除去

採取され, 腺組織, 脂肪などを含む可能性があるが，本 器はこれらを除去し, 厚さを均一にする目的でも有効で ある(図 25)。

以上, 今回開発した口蓋歯肉採取器は, 従来のものに くらべ広い幅と長さの歯肉片が採取でき, また, 口腔内 における操作性もすぐれており, 臨床応用上有用な器具 と考えている。

\section{結 論}

1. 把柄部を回転することによって刃部の彎曲を自由 にかえることができる口蓋歯肉採取器を開発した。

2. 本器は, 各個人で異なる口蓋の形態に刃部を適合 させることができ，最大面積の口蓋歯肉が容易に採取で き，また口腔内における操作性もすぐれている。

\section{謝 辞}

稿を終わるに当たり，口蓋歯肉採取器の開発にご協力いただ いた日本歯科工業社，進士春夫氏に感謝します。

\section{文献}

1) 江西基良 : 日本人の口腔人類学的研究 (その 1 ). 歯科月報, $19: 169-195,1939$. 